\title{
The McCollough effect obtained simultaneously on four orientations with four different colors
}

\author{
GEORGE W. BRIGGS and PAUL C. VITZ \\ New York University, New York, New York 10003
}

\begin{abstract}
The McCollough effect, an orientation-specific color aftereffect, typically has been demonstrated with two adaptation orientations and two colors. In the present experiment, the McCollough effect is obtained simultaneously on four orientations with four different colors.
\end{abstract}

McCollough (1965) described an orientationspecific color aftereffect. After the subjects adapted to a blue-black horizontal grating alternated with an orange-black vertical grating, they reported that a vertical black-white test grating appeared blue-green and that a horizontal black-white test grating appeared orange. McCollough attributed this aftereffect to the adaptation of orientation-specific edge detectors which also coded color.

Fidell (1970) supported McCollough's interpretation of the aftereffect. She showed that strong aftereffects could be obtained regardless of the orientations of the adapting stimuli as long as they were at right angles to each other. However, with one of the adapting stimuli kept constant at vertical, the aftereffects were much weaker when the adapting stimuli differed by $11^{\circ}$ or $22^{\circ}$ than when they differed by $45^{\circ}$ or $90^{\circ}$. These findings are consistent with the results of Campbell, Cleland, Cooper, and Enroth-Cugell (1968), who determined that the rate of firing of most orientation-sensitive units in the cat's visual cortex falls to half of its maximum value when the stimulus is rotated $14^{\circ}-26^{\circ}$ from the optimum orientation. Fidell suggested that adapting stimuli of less than $22^{\circ}$ angular divergence would not stimulate distinctly different populations of orientationsensitive neurons and, therefore, would not readily produce an aftereffect. This implies that the McCollough effect could be obtained only when the adapting stimuli affect distinctly different populations of orientation-sensitive neurons. If this is the case, one might expect to obtain orientation-specific aftercolors when more than one pair of adapting orientations is used. The present experiment demonstrates that orientation-specific aftercolors can be obtained simultaneously at four orientations by having the subjects adapt in the same session to violet-vertical, green-horizontal, orange-right-diagonal, and greenblue-left-diagonal gratings.

Requests for reprints should be sent to Paul C. Vitz, Department of Psychology, New York University, 4 Washington Place, Ninth Floor, New York, New York 10003. This research was supported by a grant to the second author from the Institute of Neurological Diseases and Stroke, National Institutes of Health (No. NS-07636-06).
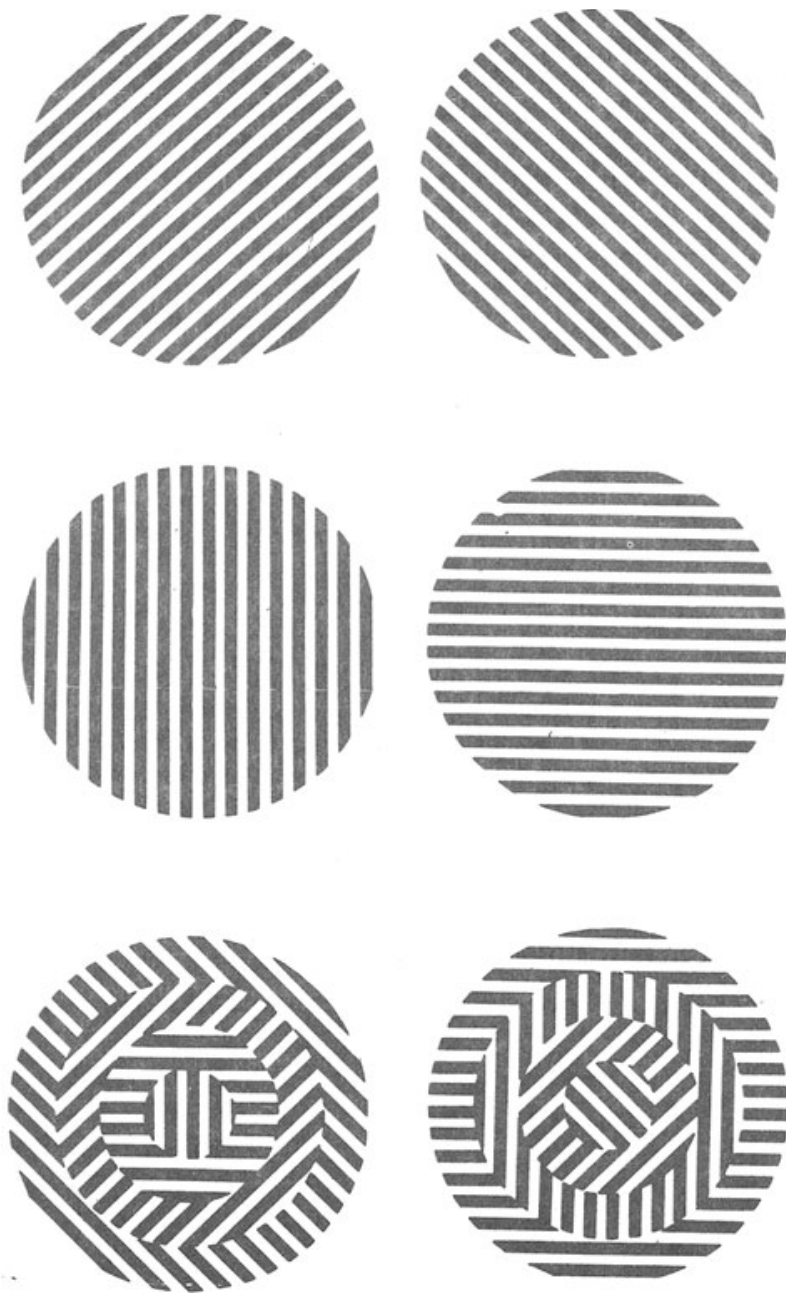

Figure 1. Top two rows: Adapting stimuli presented at right-diagonal, left-diagonal, vertical, and horizontal orientations. Bottom row: Test stimuli, each containing all four of the adapting orientations.

Subjects

\section{METHOD}

The eight subjects were male and female volunteers from the New York University psychology department. All were familiar with the basic McCollough effect.

\section{Apparatus}

Figure 1 shows the adapting and test stimuli. The adapting 
Table 1

Color Responses to the Four Orientations Present in Each Test Stimulus

\begin{tabular}{|c|c|c|c|c|c|c|c|c|}
\hline \multirow[b]{2}{*}{ Orientations } & \multicolumn{8}{|c|}{ Subjects } \\
\hline & G.B. & A.A. & P.V. & J.B. & S.C. & S.R. & G.I. & E.G. \\
\hline \multicolumn{9}{|l|}{ Test Stimulus 1} \\
\hline Right Diagonal & $\begin{array}{l}\text { Greenish- } \\
\text { blue (+) }\end{array}$ & None $(0)$ & None $(0)$ & None $(0)$ & None $(0)$ & None $(0)$ & None $(0)$ & $\begin{array}{l}\text { Bluish- } \\
\text { green (t) }\end{array}$ \\
\hline Left Diagnoal & $\begin{array}{l}\text { Yellowish- } \\
\text { orange (+) }\end{array}$ & $\begin{array}{l}\text { Yellowish- } \\
\text { orange (+) }\end{array}$ & Orange $(+)$ & $\begin{array}{l}\text { Yellowish- } \\
\text { orange (+) }\end{array}$ & None $(0)$ & $\begin{array}{l}\text { Yellowish- } \\
\text { orange ( }(+)\end{array}$ & $\begin{array}{l}\text { Yellowish- } \\
\text { orange }(+)\end{array}$ & $\begin{array}{l}\text { Pinkish- } \\
\text { red (-) }\end{array}$ \\
\hline Horizontal & $\begin{array}{l}\text { Pinkish- } \\
\text { red }(+)\end{array}$ & $\begin{array}{l}\text { Pinkish- } \\
\text { red (+) }\end{array}$ & $\begin{array}{l}\text { Pinkish- } \\
\text { red (+) }\end{array}$ & $\begin{array}{l}\text { Pinkish- } \\
\text { red (+) }\end{array}$ & $\begin{array}{l}\text { Pinkish- } \\
\text { red }(+)\end{array}$ & $\begin{array}{l}\text { Pinkish- } \\
\text { red (+) }\end{array}$ & $\begin{array}{l}\text { Pinkish- } \\
\text { red (+) }\end{array}$ & $\begin{array}{l}\text { Pinkish- } \\
\text { red (+) }\end{array}$ \\
\hline Vertical & $\begin{array}{l}\text { Yellowish- } \\
\text { green (+) }\end{array}$ & $\begin{array}{l}\text { Yellowish- } \\
\text { green }(+)\end{array}$ & Green (+) & $\begin{array}{l}\text { Bluish- } \\
\text { green (+) }\end{array}$ & Green $(+)$ & Green $(+)$ & $\begin{array}{l}\text { Yellowish- } \\
\text { green }(+)\end{array}$ & $\begin{array}{l}\text { Greenish- } \\
\text { blue (-) }\end{array}$ \\
\hline \multicolumn{9}{|l|}{ Test Stimulus 2} \\
\hline Horizontal & $\begin{array}{l}\text { Pinkish- } \\
\text { red (+) }\end{array}$ & $\begin{array}{l}\text { Pinkish- } \\
\text { red (+) }\end{array}$ & $\begin{array}{l}\text { Pinkish- } \\
\text { red }(+)\end{array}$ & $\begin{array}{l}\text { Pinkish- } \\
\text { red (+) }\end{array}$ & None $(0)$ & $\begin{array}{l}\text { Reddish- } \\
\text { orange (+) }\end{array}$ & $\begin{array}{l}\text { Pinkish- } \\
\text { red (+) }\end{array}$ & $\begin{array}{l}\text { Pinkish- } \\
\text { red (+) }\end{array}$ \\
\hline Vertical & $\begin{array}{l}\text { Yellowish- } \\
\text { green (+) }\end{array}$ & $\begin{array}{l}\text { Yellowish- } \\
\text { green }(+)\end{array}$ & Green (+) & Green $(+)$ & Green $(+)$ & Green (+) & $\begin{array}{l}\text { Yellowish- } \\
\text { green }(+)\end{array}$ & Green (+) \\
\hline Right Diagonal & $\begin{array}{l}\text { Greenish- } \\
\text { blue (+) }\end{array}$ & Blue (+) & $\begin{array}{l}\text { Bluish- } \\
\text { green (+) }\end{array}$ & $\begin{array}{l}\text { Greenish- } \\
\text { blue (+) }\end{array}$ & $\begin{array}{l}\text { Greenish- } \\
\text { blue (+) }\end{array}$ & None $(0)$ & None $(0)$ & $\begin{array}{l}\text { Bluish- } \\
\text { green (+) }\end{array}$ \\
\hline Left Diagonal & $\begin{array}{l}\text { Yellowish- } \\
\text { orange (+) }\end{array}$ & $\begin{array}{l}\text { Orangeish- } \\
\text { yellow (+) }\end{array}$ & Orange (+) & $\begin{array}{l}\text { Yellowish- } \\
\text { orange (+) }\end{array}$ & $\begin{array}{l}\text { Orangeish- } \\
\text { yellow (+) }\end{array}$ & Yellow (+) & $\begin{array}{l}\text { Yellowish- } \\
\text { orange (+) }\end{array}$ & $\begin{array}{l}\text { Pinkish- } \\
\text { red }(-)\end{array}$ \\
\hline
\end{tabular}

stimuli were black-and-white square-wave gratings of vertical $\left(0^{\circ}\right)$, horizontal $\left(90^{\circ}\right)$, right-diagonal $\left(45^{\circ}\right)$, and left-diagonal $\left(-45^{\circ}\right)$ orientation in circular fields. These were projected through violet (Wratten 34A), green (Wratten 53), orange (Wratten 21), and green-blue (Edmund Scientific 858) colored filters, respectively. Neutral-density filters were added to the green, orange, and green-blue filters so that the adapting stimuli were judged by the experimenter to have nearly equal brightnesses. Test stimuli were also in circular fields, but each contained four regions: a central circular area and three concentric annuli, as shown in Figure 1. Each region contained a square-wave grating at one of the adapting orientations. and each test stimulus contained all of the adapting orientations. Stimuli were mounted on slides and projected onto a white screen by a Kodak Carousel projector, Model 760. Each subject was provided with an answer sheet on which to write the names of any colors he say during the experiment. The alternative color names were: red, yellowish-red, pinkish-red; orange, reddish-orange, yellowish-orange; yellow, orangeish-yellow, greenish-yellow; green, yellowish-green, bluish-green; blue, greenish-blue, violet-blue; violet, bluish-violet, reddish-violet.

\section{Procedure}

The subjects, run individually or in pairs, were seated $6 \mathrm{ft}(2 \mathrm{~m})$ from the screen onto which the stimuli were projected. At that distance, the spatial frequency of the gratings in both the adapting and test stimuli was approximately 2 cycles/deg, and the diameter of the stimulus field was about $8^{\circ}$. In the test stimuli, the radius of the central circular area and the width of each of the annuli (outside radius minus inside radius) was $1^{\circ}$.

The subjects were then given the list of 18 color names to examine for a few minutes. Any questions regarding these color names were answered by the experimenter. The room lights were then turned off, and after $1 \mathrm{~min}$ of dark adaptation, the subjects were shown each of the test stimuli to determine whether any subject had a preadaptation bias to report a particular color. For each test slide, the subjects were asked to look at the light stripes in each of the four regions. If any color appeared in a region, they were told to choose the name from the list that most closely matched the color and to write that name in the appropriate space on their answer sheets. The subjects were asked to write "none" when they saw no color in a test region.

After the preadaptation test, the subjects were told that they would see a series of colored gratings, and that they should let their eyes wander around each stimulus without fixating any particular point. They were also told to hold their heads erect throughout the experiment. Subjects were then shown the adapting stimuli in a repeating series in which each stimulus was presented for $15 \mathrm{sec}$, with $1 \mathrm{sec}$ between stimuli. The series was presented 20 times so that each stimulus was presented for a total of $5 \mathrm{~min}$. The order or presentation was violet-vertical, green-horizontal, orange-rightdiagonal, and green-blue-left-diagonal.

Following adaptation, the subjects sat in dim illumination for 3 min to allow afterimages to fade. Then the subjects were asked to report any colors they saw on the test stimuli, following the same procedure as in the preadaptation test. This method of testing, having subjects choose a color name from a list, was used because it was noticed in pilot studies that subjects tend to use a restricted range of color names when they are allowed simply to report what colors they see.

\section{RESULTS AND DISCUSSION}

The postadaptation responses of the subjects are shown in Table 1 for each grating orientation in each of the test stimuli. The postadaptation responses were conservatively coded as to whether each represents approximately the complementary color of the adapting grating at that orientation. A + indicates that a response does represent the approximate complement of the adapting color, while a -indicates that it does not. A code of 0 was given to the response "none." For four subjects, the responses to at least one of the test stimuli are all coded + , indicating that these subjects experienced complementary-color aftereffects at all four of the adapting orientations. Another subject (S.C.) reported complementary colors at all four orientations, but not in the same test stimulus. Two subjects (S.R. and G.I.) reported complementary colors at only three orientations- the same three in both test stimuli. Both subjects reported "none" for the right-diagonal orientation. Only one 
subject (E.G.) reported a few colors which were coded as inappropriate. Four subjects reported color in some areas of the test stimuli in the preadaptation test. However, in most cases, these colors bore no relation to the subjects' postadaptation responses for the same areas. Therefore, it is reasonable to conclude that the postadaptation colors were due to the adaptation, not to any preexperiment bias to report colors.

This experiment demonstrates that the McColough effect can be obtained simultaneously at four orientations with four different adapting colors. Such a finding is consistent with McCollough's (1965) original interpretation of the aftereffects, and it suggests, when considered along with the findings of Fidell (1970), that orientation-contingent color aftereffects may occur at a number of orientations as long as the orientations are coded by separate populations of orientation detectors.

\section{REFERENCES}

Campbell, F. W., Cleland, B. G., Cooper, G. F., \& Enroth-Cugell, C. The angular selectivity of visual cortical cells to moving gratings. Journal of Physiology, 1968, 198, 237-250.

FIDELL, L. S. Orientation specificity in chromatic adaptation of human "edge-detectors." Perception \& Psychophysics, 1970. 8. 235-237.

McCollough, C. Color adaptation of edge-detectors in the human visual system. Science, 1965, 149, 1115-1116.

(Received for publication July 22, 1975.) 